\title{
Endoscopic Approach for Major Complications of Bariatric Surgery
}

\author{
Moon Kyung Joo \\ Division of Gastroenterology, Department of Internal Medicine, Korea University College of Medicine, Guro Hospital, Seoul, Korea
}

As lifestyle and diet patterns have become westernized in East Asia, the prevalence of obesity has rapidly increased. Bariatric surgeries, such as Roux-en-Y gastric bypass (RYGB), sleeve gastrectomy (SG), and laparoscopic adjustable gastric banding (LAGB), are considered the first-line treatment option in patients with severe obesity. However, postoperative complications have increased and the proper management of these complications, including the use of endoscopic procedures, has become important. The most serious complications, such as leaks and fistulas, can be treated with endoscopic stent placement and injection of fibrin glue, and a novel full-thickness closure over-the-scope clip (OTSC) has been used for treatment of postoperative leaks. Stricture at the gastrojejunal (GJ) anastomosis site after RYGB or incisura angularis in SG can be managed using stents or endoscopic balloon dilation. Dilation of the GJ anastomosis or gastric pouch may lead to failure of weight loss, and the use of endoscopic sclerotherapy, novel endoscopic suturing devices, and OTSCs have been attempted. Intragastric migration of the gastric band can be successfully treated using various endoscopic tools. Endoscopy plays a pivotal role in the management of post-bariatric complications, and close cooperation between endoscopists and bariatric surgeons may further increase the success rate of endoscopic procedures. Clin Endosc 2017;50:31-41

Key Words: Bariatric surgery; Complication; Endoscopic therapy

\section{INTRODUCTION}

Obesity is a major health problem, with a rapidly increasing prevalence in Asian populations as well as in Western countries. ${ }^{1}$ In Korea, the prevalence of obesity was $26.9 \%$ in 1998 and $32.0 \%$ in 2011; a significantly increased overall prevalence of obesity and abdominal obesity by 1.19 -fold and 1.24-fold, respectively, occurred from 2001 to 2011 . $^{2}$ Serious chronic diseases including diabetes mellitus (DM), hypertension, coronary heart disease, and malignancy can develop if obesity is not treated properly. Unfortunately, however, the long-term results of non-surgical treatments, such as lifestyle modifica-

Received: October 2, 2016 Accepted: November 2, 2016

Correspondence: Moon Kyung Joo

Division of Gastroenterology, Department of Internal Medicine, Korea University College of Medicine, Guro Hospital, 148 Gurodong-ro, Guro-gu, Seoul 08308, Korea

Tel: +82-2-2626-3007, Fax: +82-2-2626-1038, E-mail: latyrx@naver.com

(cc) This is an Open Access article distributed under the terms of the Creative Commons Attribution Non-Commercial License (http://creativecommons.org/ licenses/by-nc/3.0) which permits unrestricted non-commercial use, distribution, and reproduction in any medium, provided the original work is properly cited. tion, diet, and pharmacologic intervention, are unsatisfactory in severe, class III obesity (body mass index [BMI] $>40 \mathrm{~kg} / \mathrm{m}^{2}$ ), which requires surgical treatment in most cases. ${ }^{3}$

Typical bariatric surgical procedures include Roux-en-Y gastric bypass (RYGB), biliopancreatic diversion and duodenal switch (BPD-DS), laparoscopic adjustable gastric banding (LAGB), and sleeve gastrectomy (SG), which result in greater sustained weight reduction, lower incidence of type $2 \mathrm{DM}$, and lipid improvement during the long-term follow-up period over 5 years compared to non-surgical approaches. ${ }^{4}$ These procedures are now being performed globally as standard therapeutic interventions for severe obesity. However, increasing numbers of perioperative or late postoperative complications of bariatric surgery, such as anastomotic leak, bleeding, stricture, marginal ulcers, dilation of gastrojejunal (GJ) anastomosis or gastric pouch, and band erosions, have been accumulating; these complications can be life-threatening if not managed promptly. ${ }^{5}$ Accurate diagnosis and decision-making regarding reoperation is essential. However, the surgical approach may present a significant clinical burden for many patients, especially those with severe comorbidities and 
thus a high operative risk. In this situation, endoscopic therapy can be a useful alternative option for the feasible and safe management of postoperative complications associated with bariatric surgery.

This review provides an update of recent pivotal clinical outcomes and future perspectives of endoscopic management of post-bariatric surgical complications.

\section{LEAK AND FISTULA}

Gastrointestinal (GI) leak after bariatric surgery is one of the most life-threatening complications, with a mortality rate of $14 \% .^{6}$ The incidence of leak after bariatric surgery is $2.4 \%-4.9 \%$ and varies according to the type of surgery. ${ }^{6-8}$ The most frequent site of leak in patients with RYGB is the GJ anastomosis, followed by the gastric pouch and jejunojejunal anastomosis, ${ }^{8}$ whereas in a vast majority of patients with SG, the location of the leak is proximal, near the esophagogastric junction (EGJ). ${ }^{7}$ Leaks are classified according to the time of occurrence: early ( $<14$ days postoperative), intermediate (2-6 weeks), and late or delayed ( $>6$ weeks). Most post-bariatric leaks occur early. Early leaks in hemodynamically unstable patients, such as those with tachycardia, tachypnea, dyspnea, and fever, should be treated immediately, and usually require surgical cleansing with external drainage as well as basic conservative management, such as fasting, total parenteral nutrition, and administration of intravenous antibiotics. However, in cases of late or delayed leaks, non-surgical management, such as percutaneous or internal drainage using the GI tract rather than surgical debridement, may be an alternative option. Several case reports or case series regarding endoscopic drainage of postoperative fluid collection or abscess have been published. Removal of an infected abscess is performed by transluminal debridement with endoscopic aspiration and placement of a nasocystic catheter, ${ }^{9}$ or intraluminal traction of a migrated band in patients with abdominal abscess due to early migration of an adjustable gastric band.$^{10} \mathrm{~A}$ recent study demonstrated the clinical feasibility of trans-fistula drainage of an infected cyst by insertion of a double-pigtail plastic stent in 26 patients with recurrent fluid collection despite placement of a self-expandable metal stent (SEMS), showing a 79\% clinical success rate. ${ }^{11}$ Another novel technique for endoscopic internal drainage is vacuum-assisted closure, a procedure based on the insertion of a sponge in the cavity to absorb the infected fluid and accelerate the formation of granulation tissue and closure of the infected cyst. Two case series that have been published to evaluate the feasibility of vacuum-assisted

Table 1. Clinical Outcomes of Endoscopic Stent Insertion for the Management of Post-Bariatric Leaks and Fistulas

\begin{tabular}{|c|c|c|c|c|c|c|}
\hline Study & Type of stent & $\begin{array}{l}\text { Number of } \\
\text { subjects }\end{array}$ & $\begin{array}{c}\text { Type of bariatric } \\
\text { surgery }\end{array}$ & $\begin{array}{c}\text { Duration of } \\
\text { stenting (days) }\end{array}$ & $\begin{array}{l}\text { Clinical success } \\
\text { rate } \%(\mathbf{n} / \mathbf{n})\end{array}$ & Complications $(n)$ \\
\hline $\begin{array}{l}\text { Salinas et al. } \\
\qquad(2006)^{16}\end{array}$ & SEMS & 17 & RYGB & Not presented & $94(16 / 17)$ & $\begin{array}{l}\text { Esophageal mucosal tear (2), } \\
\text { migration (1) }\end{array}$ \\
\hline $\begin{array}{l}\text { Eisendrath et } \\
\text { al. }(2007)^{17}\end{array}$ & PSEMS & 21 & $\begin{array}{l}\text { RYGB (8), SG (12), } \\
\text { BPD (1) }\end{array}$ & 21 & $81(17 / 21)$ & Migration (1), stricture (2) \\
\hline $\begin{array}{l}\text { Bège et al. } \\
(2011)^{18}\end{array}$ & Not presented & 22 & RYGB, SG & 64 & $70(18 / 22)$ & Migration (13) \\
\hline $\begin{array}{l}\text { Freedman et al. } \\
(2013)^{19}\end{array}$ & Not presented & 35 & RYGB & $\begin{array}{l}\leq 14 \text { days in } \\
80 \%\end{array}$ & $86(30 / 35)$ & Migration (8) \\
\hline $\begin{array}{l}\text { El Mourad et } \\
\text { al. }(2013)^{20}\end{array}$ & PSEMS & 47 & $\begin{array}{l}\text { SG (24), RYGB (12), } \\
\text { LAGB (4), LMGB } \\
(3), \text { BPD (2), DS (1) }\end{array}$ & 45 & $87(41 / 47)$ & Migration (7), perforation (1) \\
\hline $\begin{array}{l}\text { Alazmi et al. } \\
\qquad(2014)^{21}\end{array}$ & SEMS/SEPS & 17 & SG & 42 & $76(13 / 17)$ & $\begin{array}{l}\text { Minor bleeding (2), dysphagia } \\
\text { (3), migration (1) }\end{array}$ \\
\hline $\begin{array}{l}\text { Murino et al. } \\
\qquad(2015)^{22}\end{array}$ & PSEMS & 91 & SG (55), RYGB (36) & 69 & $81(74 / 91)$ & $\begin{array}{l}\text { Esophageal stricture (13), migra- } \\
\text { tion (7), perforation (7) }\end{array}$ \\
\hline $\begin{array}{l}\text { Fishman et al. } \\
(2015)^{23}\end{array}$ & S-SEMS & 26 & SG & 28 & $65(17 / 26)$ & $\begin{array}{l}\text { Migration (7), severe bleeding (1), } \\
\text { severe intolerance ( } 4 \text { ) }\end{array}$ \\
\hline $\begin{array}{l}\text { Southwell et al. } \\
(2016)^{24}\end{array}$ & PSEMS & 21 & SG & $\begin{array}{l}\leq 14 \text { days in } \\
\quad 67 \%\end{array}$ & $95(20 / 21)$ & $\begin{array}{l}\text { Migration (10), severe intolerance } \\
\text { (5), esophageal stricture (2) }\end{array}$ \\
\hline
\end{tabular}

SEMS, self-expandable metal stent; PSEMS, partial-covered self-expandable metallic stent; SEPS, self-expandable plastic stent; S-SEMS, sleeve-customized self-expandable metal stents; RYGB, Roux-en-Y gastric bypass; SG, sleeve gastrectomy; BPD, biliopancreatic diversion; LAGB, laparoscopic adjustable gastric banding; LMGB, laparoscopic mini gastric bypass; DS, duodenal switch. 
endoscopic drainage for the treatment of leak after gastroesophageal surgery showed high clinical success rates ranging from $85 \%$ to $100 \%{ }^{12,13}$

Postoperative leak may persist even after adequate drainage of collected fluid, and further management should then be considered. In addition to drainage, there are two other main categories of endoscopic procedures related to the management of postoperative leak: coverage or closure of the defect. ${ }^{14}$ However, internal/external drainage and removal of collected fluid should precede or be combined with coverage or closure of the defect to prevent the formation of sealed-off abscesses. To cover the defect, endoscopic stent insertion has been widely performed. In particular, newly developed, partially or fully covered SEMS that are flexible and maintain patency of a narrow GI lumen, combined with a delivery system for throughthe-scope (TTS) placement via a working channel, enable endoscopists to insert stents under direct inspection of the target area. ${ }^{15}$ Table 1 summarizes the previous studies regarding clinical outcomes and complications of SEMS insertion for treatment of post-bariatric surgery leaks. The majority of bariatric surgeries are RYGB and SG, and partially covered SEMS have usually been used. ${ }^{16-24}$ The duration of stenting varies, with the median period ranging from 3 to 10 weeks. ${ }^{17,18,20-23}$ However, two studies showed that the SEMS was maintained for less than 2 weeks in more than two-thirds of patients. ${ }^{19,24}$ The clinical success rate of the procedure, which indicates complete closure of leak or fistular opening, has been acceptable, ranging from $65 \%$ to $95 \% .{ }^{16-24}$ Overall, the clinical success of stent insertion is significantly associated with shorter delay between bariatric surgery and stent insertion, because delayed stenting may lead to fibrous change and chronic fistula formation from acute leaks, and eventually to a higher failure rate of closure of leaks. Another important factor is larger leak size $(\geq 10 \mathrm{~mm}){ }^{14}$

In terms of complications, stent migration occurs most frequently. Its reported rate of occurrence varies widely, from $5 \%$ to $62 \%,{ }^{16-24}$ and more serious complications, such as perforation, have also been reported. ${ }^{20,22} \mathrm{~A}$ previous meta-analysis regarding the use of SEMS in the treatment of post-bariatric surgery leaks reported an $88 \%$ clinical success rate, and successful endoscopic stent removal was achieved in $92 \%$ of cases, while stent migration was observed in $17 \%$ of cases. ${ }^{25}$ Partially covered SEMS might be superior to fully covered SEMS for prevention of migration, because mucosal hypertrophy at both uncovered ends of the stent may reduce the risk of migration. However, embedding of both ends of stents due to mucosal hyperplasia may cause difficulty in stent removal, which can be resolved by a "stent-in stent" strategy. ${ }^{22}$ Recently, the use of tailored stents for post-bariatric surgery patients has been introduced, with some published results. For example,

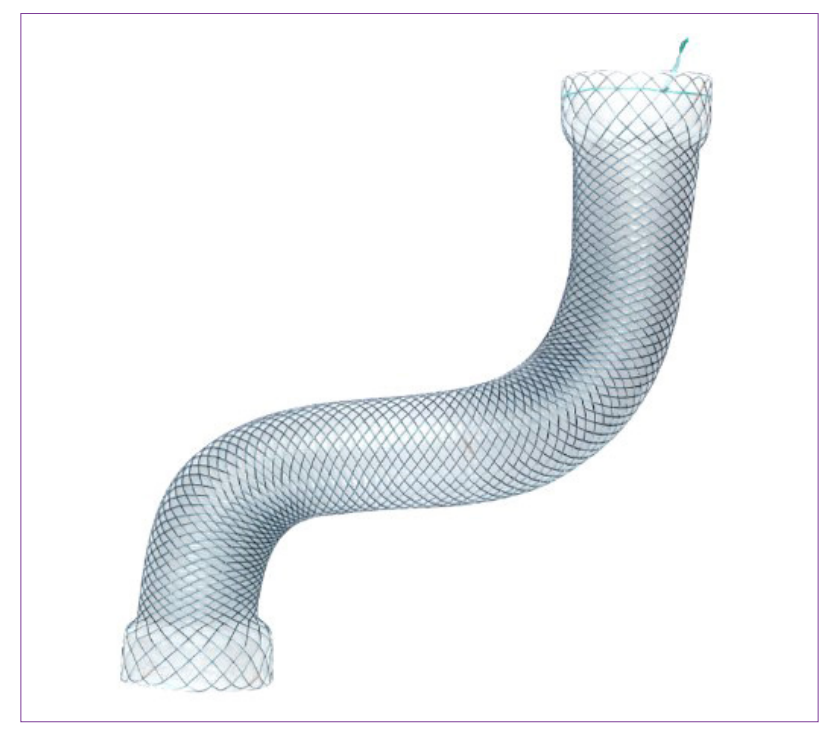

Fig. 1. Tailored stent for management of post-bariatric surgery leak. A sleeve-customized self-expandable metal stent (SEMS) with a high edge profile, allowing a more firm anchorage and longer length $(23-24 \mathrm{~cm})$ than conventional esophageal stent to bypass the entire gastric sleeve (Mega stent, Taewoong, Seoul, Korea).

several case series of novel endoscopic stents reported successful management of postoperative staple line leak in patients who underwent SG. These stents were specially designed for the treatment of post-SG leak; both ends of the stent had high profile edges allowing a more firm anchorage, and longer length $(23-24 \mathrm{~cm})$ than conventional esophageal stents, enabling the stent to bypass the entire gastric sleeve, ${ }^{23,26}$ or wider diameter $(40 \mathrm{~mm})$ to facilitate sufficient sealing of the leaks (Fig. 1). ${ }^{27}$ Large-scale, randomized, prospective studies to compare conventional and tailored stents are needed.

In comparison to coverage to lead to natural sealing of a defect, complete closure of a leak or fistula is more challenging. Endoscopic injection of Histoacryl ${ }^{28}$ or suturing devices ${ }^{29}$ have been introduced to close post-bariatric leaks or revisions. Recently, the use of fibrin sealants or an over-the-scope clip (OTSC ${ }^{\circ}$; Ovesco AG, Tübingen, Germany) has been considered the main strategy to close a leak or fistula after bariatric surgery. After debridement or clearance of infected materials, an endoscopic injection of fibrin sealant may lead to the successful closure of chronic leaks or fistulas. Multiple sessions are usually required. Several small case series showed a $100 \%$ complete closure rate of post-bariatric leak or fistula when combined with surgical or endoscopic drainage, or stent insertion (Table 2) ${ }^{30-34}$ However, it is more difficult to achieve successful closure of defects in cases of refractory gastrocutaneous (GC) fistulas, and the application of tailored long fibrin Surgisis (Cook Biotech Inc., West Lafayette, IN, USA) using acellular matrix biomaterial originating from porcine small intestine to stimulate proliferation of fibroblasts and accelerate 
Table 2. Clinical Outcomes of Endoscopic Injection of Fibrin Sealant for Closure of Post-Bariatric Leaks

\begin{tabular}{|c|c|c|c|c|c|c|}
\hline Study & $\begin{array}{l}\text { Number of } \\
\text { subjects }\end{array}$ & $\begin{array}{c}\text { Combined/precedent } \\
\text { procedures }\end{array}$ & $\begin{array}{c}\text { Type of bariatric } \\
\text { surgery }\end{array}$ & $\begin{array}{c}\text { Complete } \\
\text { closure rate (\%) }\end{array}$ & $\begin{array}{c}\text { Time for } \\
\text { closure (days) }\end{array}$ & Complications ( $n$ ) \\
\hline $\begin{array}{l}\text { Kowalski et al. } \\
(2007)^{30}\end{array}$ & 5 & Open drainage & LRYGB & 100 & 4 & None \\
\hline $\begin{array}{l}\text { Papavramidis et } \\
\text { al. }(2008)^{31}\end{array}$ & 3 & Radiologic drainage (1) & SG, BPD & 100 & Not presented & Not presented \\
\hline $\begin{array}{l}\text { Victorzon et al. } \\
(2013)^{32}\end{array}$ & 6 & $\begin{array}{l}\text { Stent (1), laparoscopic } \\
\text { drainage (5) }\end{array}$ & LRYGB & 100 & 19.5 & $\begin{array}{l}\text { Necrotizing pancreati- } \\
\text { tis (1), stricture (1) }\end{array}$ \\
\hline $\begin{array}{l}\text { Maluf-Filho et al. } \\
(2009)^{33}\end{array}$ & 25 & None & RYGB & 80 & Not presented & None \\
\hline $\begin{array}{l}\text { Toussaint et al. } \\
(2009)^{34}\end{array}$ & 5 & Stent (3) & RYGB/SG & 40 & Not presented & None \\
\hline
\end{tabular}

LRYGB, laparoscopic Roux-en-Y gastric bypass; SG, sleeve gastrectomy; BPD, biliopancreatic diversion; RYGB, Roux-en-Y gastric bypass.

Table 3. Clinical Outcomes of Over-the-Scope Clip for Closure of Post-Bariatric Leaks

\begin{tabular}{|c|c|c|c|c|c|c|}
\hline Study & $\begin{array}{l}\text { Number of } \\
\text { subjects }\end{array}$ & $\begin{array}{c}\text { Combined/precedent } \\
\text { procedures }\end{array}$ & $\begin{array}{c}\text { Type of bariatric } \\
\text { surgery }\end{array}$ & $\begin{array}{c}\text { Complete } \\
\text { closure rate (\%) }\end{array}$ & $\begin{array}{c}\text { Time for } \\
\text { closure (days) }\end{array}$ & Complications $(n)$ \\
\hline $\begin{array}{l}\text { Mercky et al. } \\
(2015)^{38}\end{array}$ & 19 & Stent (7) & $\begin{array}{l}\text { LSG (18), RYGB } \\
\text { (1) }\end{array}$ & 84 & Not presented & $\begin{array}{l}\text { Stenosis (1), anchor mi- } \\
\text { gration (1), fistula edges } \\
\text { torn by anchor (1) }\end{array}$ \\
\hline $\begin{array}{l}\text { Keren et al. } \\
(2015)^{39}\end{array}$ & 26 & $\begin{array}{l}\text { Stent }(6) \text {, biologic glue (1), } \\
\text { argon cautery (1) }\end{array}$ & LSG & 80 & 32 & None \\
\hline $\begin{array}{l}\text { Shehab et al. } \\
(2016)^{40}\end{array}$ & 12 & Mega stent (12) & RYGB, SG & 100 & Not presented & Not presented \\
\hline
\end{tabular}

LSG, laparoscopic sleeve gastrectomy; RYGB, Roux-en-Y gastric bypass; SG, sleeve gastrectomy.

tissue repair has been reported to manage chronic GC fistulas after bariatric surgeries. ${ }^{33,34}$ However, complete closure rates were relatively lower, ranging from $40 \%$ to $80 \%$, compared to other case series that included GJ leak. ${ }^{30,32}$ Combined endoscopic procedures, such as stenting, may enhance the effective implantation of fibrin plugs in fistular tracts, and thus lead to successful closure of GC fistulas. ${ }^{34}$

A novel OTSC was designed to provide full-thickness closure of GI tract defects and was first introduced to manage massive bleeding or iatrogenic perforation. ${ }^{35}$ Case reports regarding the application of OTSCs for successfully closing post-bariatric leaks and fistulas have been published. ${ }^{36,37}$ Recently, retrospective studies that enrolled larger numbers of patients have been reported and are summarized in Table $3{ }^{38-40}$ It is notable that the clinical success rate of closure of leak or fistula was relatively high, ranging from $80 \%$ to $100 \%$. In contrast, there were relatively few procedure-related complications. In one of the studies, closure of post-bariatric surgery leaks was achieved in all cases when OTSCs were applied with ultra-large expandable stents tailored for post-bariatric surgery leak (Mega stent, Taewoong Medical, Seoul, Korea) simultaneously or after stent removal. ${ }^{40}$ However, it is premature to draw conclusions regarding the superiority of OTSCs over stent insertion or injection of fibrin glue, due to the lack of clinical outcomes and comparable studies. A recent retrospective study demonstrated that the application of OTSCs in patients with postoperative leakage, iatrogenic perforation, or spontaneous rupture of the upper GI tract resulted in higher clinical success rates, shorter hospital stay or treatment duration, and fewer complications, compared with insertion of fully covered SEMS. ${ }^{41}$ However, it is difficult to apply this promising result in the management of post-bariatric leak, because the study did not include any cases of post-bariatric surgery.

\section{STRICTURE}

Postoperative stricture is one of the most frequent complications of bariatric surgery. In cases of RYGB, stricture usually develops at the GJ anastomosis site, and is caused by the use of a circular rather than linear stapler, local ischemia, or inflammatory response. ${ }^{42}$ The incisura angularis in SG is most vulnerable to postoperative stricture due to calibration of the sleeve over a tube that is too narrow or over-sewing of the staple line. ${ }^{43}$ Recently, the incidence of postoperative stricture after bariatric surgery has been reported as $3.7 \%-7.8 \%$ at the 
Table 4. Clinical Outcomes of Endoscopic Ballooning for Management of Post-Bariatric Stricture

\begin{tabular}{|c|c|c|c|c|c|c|c|}
\hline Study & $\begin{array}{c}\text { Type of } \\
\text { bariatric } \\
\text { surgery }\end{array}$ & $\begin{array}{l}\text { Number } \\
\text { of subjects }\end{array}$ & $\begin{array}{l}\text { Time to } \\
\text { diagnosis } \\
\text { (days) }\end{array}$ & $\begin{array}{l}\text { Balloon diameter } \\
\quad(\text { type, } \mathrm{mm})\end{array}$ & $\begin{array}{l}\text { Number } \\
\text { of session }\end{array}$ & $\begin{array}{l}\text { Clinical } \\
\text { success } \\
\text { rate }(\%)\end{array}$ & $\begin{array}{c}\text { Complications } \\
(n, \%)\end{array}$ \\
\hline $\begin{array}{l}\text { Carrodeguas et al. } \\
(2006)^{44}\end{array}$ & RYGB & 94 & 52.7 & CRE, up to 16.5 & $1-4$ & 100 & Perforation $(2,2.1)$ \\
\hline Peifer et al. $(2007)^{45}$ & RYGB & 43 & 49.7 & CRE, 15.5 & $1-2$ & 93 & None \\
\hline Ukleja et al. $(2008)^{46}$ & RYGB & 61 & 60 & CRE, up to 18 & $1-5$ & 100 & Perforation $(3,4.9)$ \\
\hline $\begin{array}{l}\text { Da Costa et al. } \\
(2011)^{47}\end{array}$ & RYGB & 105 & 90 & CRE, up to 16 & $1-4$ & 100 & Perforation $(3,1.8)$ \\
\hline $\begin{array}{l}\text { Ahmad et al. } \\
\qquad(2003)^{53}\end{array}$ & RYGB & 14 & 81 & CRE, up to 18 & $1-7$ & 100 & None \\
\hline Go et al. $(2004)^{54}$ & RYGB & 38 & 54 & CRE, up to 16 & $1-6$ & 95 & Perforation $(1,2.6)$ \\
\hline Rossi et al. $(2005)^{49}$ & RYGB & 38 & Not presented & CRE, up to 15 & $1-4$ & 100 & $\begin{array}{l}\text { Nausea and vomiting } \\
(1,2.6)\end{array}$ \\
\hline $\begin{array}{l}\text { Catalano et al. } \\
(2007)^{55}\end{array}$ & RYGB & 26 & 38 & CRE, up to 15 & $1-7$ & 96 & None \\
\hline $\begin{array}{l}\text { Campos et al. } \\
(2010)^{56}\end{array}$ & RYGB $^{\text {a) }}$ & 35 & Not presented & Achalasia, 30 & $1-4$ & 100 & Hemorrhage $(1,2.8)$ \\
\hline Parikh et al. $(2012)^{50}$ & SG & 8 & 48 & CRE, 16 & $1-2$ & 100 & Not presented \\
\hline Ogra et al. $(2015)^{51}$ & SG & 26 & 49 & $\begin{array}{l}\text { CRE, up to } 20 \\
\text { Achalasia, up to } 30\end{array}$ & $1-4$ & 100 & None \\
\hline
\end{tabular}

RYGB, Roux-en-Y gastric bypass; SG, sleeve gastrectomy; CRE, Controlled Radial Expansion.

${ }^{a)}$ Gastric pouch outlet stenosis due to ring slippage.

GJ anastomosis site in RYGB. ${ }^{44-47}$ However, several previous studies that included the early period of RYGB surgery cases (2000-2005) reported a relatively high incidence of postoperative stricture, ranging from $11 \%$ to $17 \%{ }^{48,49}$ Symptomatic stenosis after SG usually develops in the incisura angularis, and its incidence has been reported as 3.0\%-3.5\%. ${ }^{50,51}$ Significant stricture usually develops during the first 3 months of the postoperative period and, if clinically suspected, prompt diagnostic endoscopy and evaluation of stricture should be performed because endoscopic dilation of early postoperative stricture (within 90 days after surgery) is more effective than that of late stricture, which may lead to revisional surgery. ${ }^{52}$

Since the introduction of TTS endoscopy, endoscopic balloon dilation of postoperative stricture has become generally accepted as an effective and safe therapeutic tool. Details of endoscopic balloon dilation procedures and clinical outcomes are summarized in Table $4 .^{44-47,49-51,53-56}$ Most of the significant strictures are found during the first 3 months after surgery, and a proportion of patients require repeat dilation, ranging from 2 to 4 sessions and even up to 7 sessions. The clinical success rate of balloon dilation, which indicates resolution of obstructive symptoms and passage of the endoscope without disturbance, was promising, with rates exceeding $90 \%$. However, serious complications including perforation were reported in $2 \%-5 \%$ of cases. Recent data have indicated that the number of dilation sessions and ischemic segments in the stricture site are significant risk factors for perforation, while the ischemic segment and fistula have been positively associated with dilation failure. ${ }^{57}$ In most strictures at the GJ anastomosis site in RYGB, the Controlled Radial Expansion (CRE) balloon (Boston Scientific Corporation, Marlborough, MA, USA) is effective when dilated up to $18 \mathrm{~mm}$ in diameter. However, a larger dilator is required in cases of complications such as gastric pouch stenosis or after SG. For example, Campos et al. showed that gastric pouch outlet stenosis due to silastic ring slippage after RYGB was successfully managed with preliminary dilation using a Savary dilator (Cook Biotech Inc.) or a CRE balloon dilated up to $20 \mathrm{~mm}$, followed by definitive dilation using a $30-\mathrm{mm}$ achalasia balloon. ${ }^{56}$ Ogra et al. also reported successful treatment of fixed stenosis at the incisura angularis after SG with conventional CRE balloon dilation followed by use of a 30-mm achalasia balloon. ${ }^{51}$

The placement of a stent at the stricture site has been also reported. However, the number of subjects and studies has been small, and only small case series have been reported up to now. The clinical success rate of stent insertion varies widely, ranging from $12.5 \%$ to $100 \% .{ }^{58,59}$ It is necessary to evaluate the clinical feasibility and effectiveness of stent insertion for the treatment of post-bariatric surgery stricture by accumulating more clinical experiences with greater numbers of subjects. 


\section{GI HEMORRHAGE}

Generally, acute GI bleeding is more common in RYGB, in which its occurrence ranges from $1 \%$ to $5 \%$, than in LAGB or SG, and it occurs more frequently in laparoscopic RYGB than open RYGB. Most bleeding occurs during the early postoperative phase within 3 days after surgery, and extraluminal bleeding accounts for half of the cases. ${ }^{43,60,61}$ Tachycardia, decrease of hemoglobin or hematocrit, hematemesis, and melena are common clinical signs and symptoms, and the staple line is the most common specific source of bleeding, although generalized oozing without a specific source is also common. ${ }^{62}$ If GI bleeding is considered extraluminal, abdominal imaging, such as a computed tomography (CT) scan, should be performed promptly to determine the bleeding site, and emergent surgical intervention is mandatory. If intraluminal bleeding is suspected at the gastrojejunostomy site, esophagogastroduodenoscopy may be performed for diagnosis, and a therapeutic endoscopic procedure can be performed at the same time, if feasible. However, it is challenging to diagnose jejunojejunostomy site bleeding, and push enteroscopy or balloon-assisted enteroscopy may be helpful. ${ }^{63}$ Unfortunately, data from endoscopic homeostasis of post-bariatric surgical GI bleeding is still lacking. Jamil et al. showed that none of 24 patients who underwent endoscopic intervention required surgery to control GI hemorrhage, although $17 \%$ (5/24) patients required second- or third-look endoscopy with intervention. ${ }^{64}$ Endoscopic procedures include epinephrine injection, heater probe, or clipping. However, heater probe therapy should be performed with caution, especially if bleeding originates from the staple line, due to the high risk of perforation. ${ }^{64}$
In contrast to early postoperative GI hemorrhage, most late GI bleeding is caused by ulcers on the jejunal side near the GJ anastomosis site (i.e., marginal ulcers). The incidence of marginal ulcer is reported as $0.6 \%-16 \%$, and most cases develop in the first 2-4 months after surgery. ${ }^{65}$ Risk factors for marginal ulcers are multiple. Procedure-related factors include pouch orientation and size, staple line dehiscence, tension at the GJ anastomosis, and circular stapled anastomosis. Other major factors including long-term use of non-steroidal anti-inflammatory drugs (NSAIDs), Helicobacter pylori infection, alcohol, smoking, and DM also influence the development of marginal ulcers. ${ }^{43} \mathrm{H}$. pylori infection status should be tested, and eradication therapy performed if positive. The use of NSAIDs should be minimized or a physician should consider the concomitant use of proton pump inhibitors, mucosal protective agents, or sucralfate solution.

\section{DILATION OF GJ ANASTOMOSIS OR GASTRIC POUCH}

After undergoing RYGB surgery, some patients suffer from weight regain and endoscopic examination reveals a significantly dilated GJ anastomosis or pouch. A previous study showed that gastric pouch length and stoma diameter were significantly enlarged in patients with weight regain compared to patients with sustained weight loss, and these measures were inversely correlated with excess weight loss. Furthermore, stoma diameter was an independent factor for weight regain after RYGB; the author suggested the upper limit of "normal" stoma diameter as $2.0 \mathrm{~cm} .{ }^{66}$ Thus, revision of

Table 5. Clinical Outcomes of Endoscopic Sclerotherapy for Management of Dilated Gastrojejunal Anastomosis after Roux-en-Y Gastric Bypass

\begin{tabular}{lccccccc}
\hline Study & $\begin{array}{c}\text { Number of } \\
\text { subjects }\end{array}$ & $\begin{array}{c}\text { Number of } \\
\text { session }\end{array}$ & $\begin{array}{c}\text { Follow-up } \\
\text { period } \\
(\mathbf{m o n t h})\end{array}$ & $\begin{array}{c}\text { Diameter of } \\
\text { GJA } \\
(\mathbf{m m})^{\text {a) }}\end{array}$ & $\begin{array}{c}\text { Loss of } \\
\text { weight } \\
(\mathbf{k g})\end{array}$ & $\begin{array}{c}\text { Clinical } \\
\text { success rate } \\
(\%)\end{array}$ & Complications \\
\hline Spaulding (2003) & 20 & 1.3 & 6 & $9-10$ & -6.8 & 75 & Vomiting, epigastric pain \\
$\begin{array}{l}\text { Spaulding et al. } \\
(2007)^{69}\end{array}$ & 32 & 1.8 & $>12$ & 10 & $-0.39 /$ & 90.7 & Not presented \\
$\begin{array}{l}\text { Catalano et al. } \\
(2007)^{70}\end{array}$ & 28 & 2.3 & 18 & 12.7 & -19.9 & 64 & Stenosis \\
$\begin{array}{l}\text { Loewen et al. } \\
(2008)^{71}\end{array}$ & 71 & 1.6 & 12 & Not presented & -8.6 & 72 & Epigastric pain \\
$\begin{array}{l}\text { Abu Dayyeh et al. } \\
(2012)^{73}\end{array}$ & 231 & 2 & 12 & Not presented & $-4.5^{\text {b) }}$ & 76 & Bleeding, pain \\
$\begin{array}{l}\text { Giurgius et al. } \\
(2014)^{72}\end{array}$ & 48 & 2 & 22 & Not presented & -7.2 & 58 & Not presented \\
\hline
\end{tabular}

GJA, gastrojejunal anastomosis.

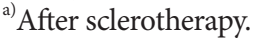

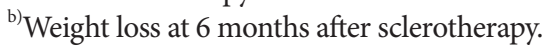


dilated gastric pouch or GJ anastomosis is an important issue for maintenance of the clinical effect of RYGB, and the endoscopic approach is safe and feasible.

The first endoscopic procedure developed to manage the dilated gastrojejunostomy was sclerotherapy. A sclerosing agent (usually $5 \%$ sodium morrhuate) is injected around the anastomosis site (1-2 cc/site, total 10-30 cc/session) and multiple sessions are performed until the diameter of the GJ anastomosis becomes $12 \mathrm{~mm}$ or smaller. ${ }^{67}$ The clinical outcomes of sclerotherapy in patients with dilated GJ stoma are summarized in Table 5. ${ }^{68-72}$ Overall, 1.3-2.0 sessions of sclerotherapy were performed and the GJ stoma was adjusted to $10-12 \mathrm{~mm}$. Loss of weight after injection varied from 6.8 to $19.9 \mathrm{~kg}$. The clinical success rate, defined as achievement of weight loss or weight stabilization with no further regain, was 58\%-90\%. At present, sclerotherapy appears to be a safe, technically feasible, and repeatable procedure with very few complications. However, its clinical efficacy in terms of weight loss is modest and longterm follow-up data with larger number of patients remain lacking. ${ }^{67}$ Abu Dayyeh et al. published a large-scale retrospective study including 231 consecutive patients undergoing 575 sclerotherapy procedures; a greater amount of weight regain from nadir and multiple sclerotherapy sessions were significant predictors for better clinical outcomes with sclerothera- py. ${ }^{73}$ However, the study had a relatively short-term follow-up of 12 months. Evaluation with a long-term follow-up period is needed.

Recently, endoscopic suturing devices have been developed for the treatment of dilated GJ anastomosis and gastric pouch. The Bard EndoCinch suturing system (C.R. BARD, Inc., Murray Hill, NJ, USA) is a device for use in the early period that attaches a suture capsule at the end of the endoscope to pull the tissues into the capsule and then sutures and ties using a needle and a knot pusher, tag pusher, and suture cutter. This device was first used for the treatment of patients with gastroesophageal reflux disorder, ${ }^{74}$ and then applied to the management of dilated GJ stoma after RYGB. Thompson et al. published a case series including 8 patients with weight regain and dilated GJ anastomosis after RYGB, and showed that 6 of 8 patients had $10 \mathrm{~kg}$ of weight loss at 4 months after the procedure, and the diameter of GJ anastomosis was reduced to 10 $\mathrm{mm} .{ }^{75}$ The same authors presented a double-blind, randomized, controlled, multicenter study of 77 subjects with postRYGB weight regain and dilated gastrojejunostomy. With a mean number of 4 stiches, the mean weight loss at 4 months after the procedure was significantly greater in the endoscopic stich group compared with that in the sham group (4.7\% vs. $1.9 \%, p=0.041)$ and the percentage of subjects who achieved

Table 6. Clinical Outcomes of Endoscopic Suturing and Plication for Management of Dilated Gastrojejunal Anastomosis or Gastric Pouch after Roux-en-Y Gastric Bypass

\begin{tabular}{|c|c|c|c|c|c|c|c|}
\hline Study & $\begin{array}{l}\text { Number of } \\
\text { subjects }\end{array}$ & $\begin{array}{l}\text { Follow-up } \\
\text { period } \\
\text { (month) }\end{array}$ & $\begin{array}{c}\text { Number of } \\
\text { plications or } \\
\text { anchors }\end{array}$ & $\begin{array}{l}\text { Reduction of } \\
\text { GJA or pouch } \\
(\%)\end{array}$ & $\begin{array}{c}\text { Loss of } \\
\text { weight }(\mathrm{kg})\end{array}$ & $\begin{array}{c}\text { Excess weight } \\
\text { loss }(\%)\end{array}$ & Complications \\
\hline \multicolumn{8}{|l|}{ StomaphyX } \\
\hline Mikami et al. $(2010)^{77}$ & 39 & 12 & 17 & Not presented & -10 & 19.5 & $\begin{array}{l}\text { Dumping syndrome, } \\
\text { pigastric pain }\end{array}$ \\
\hline Ong'uti et al. $(2013)^{79}$ & 27 & 12 & 4 & Not presented & $\begin{array}{c}\text { Not } \\
\text { presented }\end{array}$ & 47 & Reflux \\
\hline Goyal et al. $(2013)^{78}$ & 59 & 41 & 21 & $\begin{array}{l}47 \text { (GJA), } 20 \\
\text { (pouch) }\end{array}$ & $-3.8 \rightarrow-1.7^{\mathrm{a})}$ & $11.5 \rightarrow 4.3^{\mathrm{a})}$ & None \\
\hline \multicolumn{8}{|c|}{ Incisionless Operating Platform } \\
\hline Ryou et al. $(2009)^{80}$ & 5 & 3 & 7.6 & $\begin{array}{l}70 \text { (GJA), } 55 \\
\text { (pouch) }\end{array}$ & -7.8 & Not presented & Nausea and vomiting \\
\hline Mullady et al. $(2009)^{81}$ & 20 & 3 & 5 & $\begin{array}{c}65 \text { (GJA), } 36 \\
\text { (pouch) }\end{array}$ & -8.8 & Not presented & Bloating, sore throat \\
\hline Borao et al. $(2010)^{82}$ & 21 & 6 & 5.3 & $\begin{array}{l}53 \text { (GJA), } 41 \\
\quad \text { (pouch) }\end{array}$ & -7.8 & 18 & Not presented \\
\hline Horgan et al. $(2010)^{83}$ & 116 & 6 & 5.9 & $\begin{array}{l}50(\text { GJA }), 44 \\
\quad \text { (pouch) }\end{array}$ & -7.8 & 21.5 & $\begin{array}{l}\text { Pharyngitis }(41 \%), \\
\text { nausea and vomiting } \\
(12 \%), \text { pain }(11 \%)\end{array}$ \\
\hline Raman et al. $(2011)^{84}$ & 37 & 4.7 & Not presented & 52 (GJA) & -4.2 & 23.5 & Abdominal pain \\
\hline
\end{tabular}

GJA, gastrojejunal anastomosis.

${ }^{a)}$ Difference between the best outcomes and at the data at the end of follow-up. 
weight loss or weight stabilization was also significantly higher in the endoscopic stich group ( $96 \%$ vs. $78 \%, p=0.041$ ). However, the authors could not show a sustained significant difference at 6 months $(4.2 \%$ vs. $1.9 \%, p=0.066){ }^{76}$

The Stomaphy $\mathrm{X}^{\mathrm{ma}}$ endoluminal fastener and delivery system (EndoGastric Solutions, Redmond, WA, USA) is a novel endoscopic tissue approximation device. It utilizes 7-mm, 3-0 polypropylene $\mathrm{H}$-fasteners to create endoluminal plication by suctioning full-thickness, serosa-to-serosa gastric wall and firing the polypropylene H-fasteners. ${ }^{77,78}$ Endoluminal suturing using Stomaphy $\mathrm{X}^{\text {sux }}$ has been applied for the management of dilated GJ anastomosis and pouch. ${ }^{77-79}$ The percentage of effective weight loss, defined as weight loss divided by excess body weight, has varied from $20 \%$ to $47 \%{ }^{77,79}$ However, Goyal et al. reported disappointing long-term follow-up data, in which the best clinical outcomes of weight loss and reduction of GJ anastomosis and pouch were achieved at 6 months after the procedure but were diminished at the end of follow-up at 41 months (Table 6). ${ }^{78}$ Another second-generation endoscopic suturing device is the restorative obesity surgery endoscopic (ROSE) device, which contains a multi-lumen system to work as operating channels. This Incisionless Operating Platform (IOP) enables the creation of a full-thickness tissue plication using a tissue approximator (g-Prox), tissue grasper (g-Lix), and expandable tissue anchoring system (g-Cath). ${ }^{80}$ The shortterm clinical outcomes have been acceptable, with 50\%-70\% reduction in the diameter of GJ anastomosis and 36\%-55\% reduction of pouch size, $4.2-8.8 \mathrm{~kg}$ weight loss, $18 \%-23 \%$ excess weight loss, and only minor complications (Table 6). ${ }^{80-84} \mathrm{How}-$ ever, the most remarkable shortcomings of previous studies of the ROSE procedure for post-RYGB dilation are the lack of long-term follow-up data and the risk that weight regain may exist. Another problem is that the aforementioned novel devices are no longer clinically available, and more efforts need to be made to improve the long-term clinical efficacy and durability.

Meanwhile, the application of OTSC for revision of dilated GJ anastomosis and management of post-RYGB weight regain has also been reported. Heylen et al. applied the OTSC to 94 patients with RYGB and weight gain and dilated gastrojejunostomy, and reported that the diameter of GJ anastomosis was reduced from $45 \mathrm{~mm}$ to $8 \mathrm{~mm}$ by 1 or 2 sessions of OTSC clipping, with BMI dropping from $45.8 \mathrm{~kg} / \mathrm{m}^{2}$ before the procedure to $27.4 \mathrm{~kg} / \mathrm{m}^{2}$ at 1 year after the procedure. ${ }^{85}$ Further clinical experiences and data are required to support this reported efficacy.

\section{BAND EROSION}

The use of a silastic band or ring is very common in vertical gastroplasty or LAGB, and even in RYGB, and it may cause several complications, such as band slippage, gastric pouch outlet stenosis, and band erosion during its long-term placement around the upper stomach just below the EGJ. Among these complications, band erosion, the late process of intragastric band migration, may lead to loss of satiety, weight regain, and even infection at the port site, although most patients are asymptomatic. ${ }^{86}$ The incidence of band erosion is variable and has been reported as $0.3 \%-1.9 \%$ among large-scale studies that included more than 100 patients, and a recent systemic review of 15,775 patients who underwent LAGB reported an overall incidence of $1.5 \%{ }^{87}$

Once band migration and erosion occur, removal of the band should be considered owing to the possibility of complications. Surgical removal using the laparoscopic transabdominal approach is the classic method. However, endoscopic removal is feasible after extraction of the adjustable port via subcutaneous exploration. This endoscopic approach has the advantage over surgery in terms of avoiding serious morbidity or secondary surgery. However, it should be performed in cases when $>50 \%$ of the intragastric band is visible to avoid serious complications, such as bleeding or intra-abdominal or subcutaneous infection. ${ }^{43}$ To induce and accelerate the process of band erosion, temporary insertion of fully covered stents may be considered for 1-2 weeks for induction of pressure necrosis of the gastric wall between the band and stent ${ }^{88}$ or cutting of the tissue bridge to release the intragastric band using a standard papillotome and argon plasma coagulation (APC) ${ }^{89}$ Recently, Marins Campos et al. reported that induction of intragastric band erosion using a self-expandable plastic stent was effective for removal of a non-eroded band in 41 patients with banded RYGB who experienced food intolerance due to banding of the gastric pouch..$^{90}$ Successful removal of the band was achieved in all patients, after which food intolerance was improved in 32 patients (78.0\%), and 9 patients $(22.0 \%)$ required additional endoscopic balloon dilation after removal of the stent. ${ }^{90}$

When sufficient intragastric band migration and erosion is observed, cutting of the band should be performed, various devices have been used for endoscopic cutting, including APC $^{91}$ or endoscopic scissors. ${ }^{92}$ The metallic thread of the gastric-band-cutter device (Agency for Medical Innovations $\mathrm{GmbH}$, Feldkirch, Austria) is also an effective option for cutting the bands. A metallic thread is introduced through the working channel to form a loop around the band, pulled back to the mouth to connect both ends of the metallic thread to the external cutting device, and cut by twisting the handle of the external gastric-band-cutter (tourniquet technique). ${ }^{93,94}$ Once the band is successfully cut, extraction of the band can be easily performed using a snare or large grasping forceps. 
The technical success rate of endoscopic removal of a gastric band has been reported to be $92 \%-95 \%$ in two large-scale retrospective studies that each included more than 50 cases. ${ }^{95,96}$ The most worrisome complication is pneumoperitoneum, which can be treated with conservative management, but which sometimes requires laparoscopic surgery. ${ }^{94,95}$

\section{CONCLUSION AND FUTURE PERSPECTIVES}

Bariatric surgery, which currently plays a pivotal role in the curative management of morbid obesity, has mainly been performed in Western countries. However, as the numbers of patients with DM and metabolic syndrome increase, bariatric surgery is being performed more and more frequently in East Asia, and the associated complications are expected to increase accordingly. ${ }^{97}$ Thus, endoscopists must be familiar with the process and types of bariatric surgery, the main complications, and the feasibility and safety of the endoscopic approach to successfully manage post-bariatric complications. Furthermore, an optimal approach should be considered first through close collaboration and thorough discussion with bariatric surgeons to avoid serious morbidity. Meanwhile, primary endoscopic gastroplasty is being attempted with the use of various novel endoscopic suturing devices, ${ }^{98}$ and endoscopists are expected to become the first-line providers in the optimal management of serious obesity and refractory DM in the near future.

\section{Conflicts of Interest}

The author has no financial conflicts of interest.

\section{REFERENCES}

1. Koh JC, Loo WM, Goh KL, et al. Asian consensus on the relationship between obesity and gastrointestinal and liver diseases. J Gastroenterol Hepatol 2016;31:1405-1413.

2. Kim CS, Ko SH, Kwon HS, et al. Prevalence, awareness, and management of obesity in Korea: data from the Korea national health and nutrition examination survey (1998-2011). Diabetes Metab J 2014;38:35-43.

3. Padwal R, Klarenbach S, Wiebe N, et al. Bariatric surgery: a systematic review of the clinical and economic evidence. J Gen Intern Med 2011;26:1183-1194

4. Courcoulas AP, Yanovski SZ, Bonds D, et al. Long-term outcomes of bariatric surgery: a national institutes of health symposium. JAMA Surg 2014;149:1323-1329.

5. Walsh C, Karmali S. Endoscopic management of bariatric complications: a review and update. World J Gastrointest Endosc 2015;7:518-523.

6. Almahmeed T, Gonzalez R, Nelson LG, Haines K, Gallagher SF, Murr MM. Morbidity of anastomotic leaks in patients undergoing Roux-en-Y gastric bypass. Arch Surg 2007;142:954-957.

7. Aurora AR, Khaitan L, Saber AA. Sleeve gastrectomy and the risk of leak: a systematic analysis of 4,888 patients. Surg Endosc 2012;26:1509-
1515 .

8. Ballesta C, Berindoague R, Cabrera M, Palau M, Gonzales M. Management of anastomotic leaks after laparoscopic Roux-en-Y gastric bypass. Obes Surg 2008;18:623-630.

9. Lemmers A, Tan DM, Ibrahim M, et al. Transluminal or percutaneous endoscopic drainage and debridement of abscesses after bariatric surgery: a case series. Obes Surg 2015;25:2190-2199.

10. Campos JM, Evangelista LF, Neto MP, et al. Translumenal endoscopic drainage of abdominal abscess due to early migration of adjustable gastric band. Obes Surg 2010;20:247-250.

11. Bouchard S, Eisendrath P, Toussaint E, et al. Trans-fistulary endoscopic drainage for post-bariatric abdominal collections communicating with the upper gastrointestinal tract. Endoscopy 2016;48:809-816.

12. Bludau M, Hölscher AH, Herbold T, et al. Management of upper intestinal leaks using an endoscopic vacuum-assisted closure system (E-VAC). Surg Endosc 2014;28:896-901.

13. Ahrens M, Schulte T, Egberts J, et al. Drainage of esophageal leakage using endoscopic vacuum therapy: a prospective pilot study. Endoscopy 2010;42:693-698.

14. Eisendrath P, Deviere J. Major complications of bariatric surgery: endoscopy as first-line treatment. Nat Rev Gastroenterol Hepatol 2015;12:701710.

15. Choi WJ, Park JJ, Park J, et al. Effects of the temporary placement of a self-expandable metallic stent in benign pyloric stenosis. Gut Liver 2013;7:417-422

16. Salinas A, Baptista A, Santiago E, Antor M, Salinas H. Self-expandable metal stents to treat gastric leaks. Surg Obes Relat Dis 2006;2:570-572.

17. Eisendrath $\mathrm{P}$, Cremer M, Himpens J, Cadière GB, Le Moine $O$, Devière J. Endotherapy including temporary stenting of fistulas of the upper gastrointestinal tract after laparoscopic bariatric surgery. Endoscopy 2007;39:625-630

18. Bège $\mathrm{T}$, Emungania $\mathrm{O}$, Vitton $\mathrm{V}$, et al. An endoscopic strategy for management of anastomotic complications from bariatric surgery: a prospective study. Gastrointest Endosc 2011;73:238-244.

19. Freedman J, Jonas E, Näslund E, Nilsson H, Marsk R, Stockeld D. Treatment of leaking gastrojejunostomy after gastric bypass surgery with special emphasis on stenting. Surg Obes Relat Dis 2013;9:554-558.

20. El Mourad H, Himpens J, Verhofstadt J. Stent treatment for fistula after obesity surgery: results in 47 consecutive patients. Surg Endosc 2013;27:808-816.

21. Alazmi W, Al-Sabah S, Ali DA, Almazeedi S. Treating sleeve gastrectomy leak with endoscopic stenting: the Kuwaiti experience and review of recent literature. Surg Endosc 2014;28:3425-3428.

22. Murino A, Arvanitakis M, Le Moine O, Blero D, Devière J, Eisendrath P. Effectiveness of endoscopic management using self-expandable metal stents in a large cohort of patients with post-bariatric leaks. Obes Surg 2015;25:1569-1576.

23. Fishman S, Shnell M, Gluck N, Meirsdorf S, Abu-Abeid S, Santo E. Use of sleeve-customized self-expandable metal stents for the treatment of staple-line leakage after laparoscopic sleeve gastrectomy. Gastrointest Endosc 2015;81:1291-1294.

24. Southwell T, Lim TH, Ogra R. Endoscopic therapy for treatment of staple line leaks post-laparoscopic sleeve gastrectomy (LSG): experience from a large bariatric surgery centre in New Zealand. Obes Surg 2016;26:1155-1162.

25. Puli SR, Spofford IS, Thompson CC. Use of self-expandable stents in the treatment of bariatric surgery leaks: a systematic review and meta-analysis. Gastrointest Endosc 2012;75:287-293.

26. Galloro G, Magno L, Musella M, Manta R, Zullo A, Forestieri P. A novel dedicated endoscopic stent for staple-line leaks after laparoscopic sleeve gastrectomy: a case series. Surg Obes Relat Dis 2014;10:607-611.

27. Fischer A, Bausch D, Richter-Schrag HJ. Use of a specially designed partially covered self-expandable metal stent (PSEMS) with a $40-\mathrm{mm}$ diameter for the treatment of upper gastrointestinal suture or staple line leaks in 11 cases. Surg Endosc 2013;27:642-647. 
28. Lee YC, Na HG, Suh JH, Park I-S, Chung KY, Kim NK. Three cases of fistulae arising from gastrointestinal tract treated with endoscopic injection of Histoacryl. Endoscopy 2001;33:184-186.

29. Overcash WT. Natural orifice surgery (NOS) using StomaphyX for repair of gastric leaks after bariatric revisions. Obes Surg 2008;18:882-885.

30. Kowalski C, Kastuar S, Mehta V, Brolin RE. Endoscopic injection of fibrin sealant in repair of gastrojejunostomy leak after laparoscopic Rouxen- $Y$ gastric bypass. Surg Obes Relat Dis 2007;3:438-442.

31. Papavramidis TS, Kotzampassi K, Kotidis E, Eleftheriadis EE, Papavramidis ST. Endoscopic fibrin sealing of gastrocutaneous fistulas after sleeve gastrectomy and biliopancreatic diversion with duodenal switch. J Gastroenterol Hepatol 2008;23:1802-1805.

32. Victorzon M, Victorzon S, Peromaa-Haavisto P. Fibrin glue and stents in the treatment of gastrojejunal leaks after laparoscopic gastric bypass: a case series and review of the literature. Obes Surg 2013;23:1692-1697.

33. Maluf-Filho F, Hondo F, Halwan B, de Lima MS, Giordano-Nappi $\mathrm{JH}$, Sakai P. Endoscopic treatment of Roux-en-Y gastric bypass-related gastrocutaneous fistulas using a novel biomaterial. Surg Endosc 2009;23:1541-1545.

34. Toussaint E, Eisendrath P, Kwan V, Dugardeyn S, Devière J, Le Moine O. Endoscopic treatment of postoperative enterocutaneous fistulas after bariatric surgery with the use of a fistula plug: report of five cases. Endoscopy 2009;41:560-563.

35. Kim JH, Park JJ, Jung IW, et al. Treatment of traumatic esophagopleural fistula using the over-the-scope-clip system. Clin Endosc 2015;48:440443.

36. Aly A, Lim HK. The use of over the scope clip (OTSC) device for sleeve gastrectomy leak. J Gastrointest Surg 2013;17:606-608.

37. Iacopini F, Di Lorenzo N, Altorio F, Schurr MO, Scozzarro A. Over-thescope clip closure of two chronic fistulas after gastric band penetration. World J Gastroenterol 2010;16:1665-1669.

38. Mercky P, Gonzalez JM, Aimore Bonin E, et al. Usefulness of overthe-scope clipping system for closing digestive fistulas. Dig Endosc 2015;27:18-24.

39. Keren D, Eyal O, Sroka G, et al. Over-the-scope clip (OTSC) system for sleeve gastrectomy leaks. Obes Surg 2015;25:1358-1363.

40. Shehab HM, Hakky SM, Gawdat KA. An endoscopic strategy combining mega stents and over-the-scope clips for the management of post-bariatric surgery leaks and fistulas (with video). Obes Surg 2016;26:941-948.

41. Farnik H, Driller M, Kratt T, et al. Indication for 'Over the scope' (OTS)clip vs. covered self-expanding metal stent (cSEMS) is unequal in upper gastrointestinal leakage: results from a retrospective head-to-head comparison. PLoS One 2015;10:e0117483.

42. Giordano S, Salminen P, Biancari F, Victorzon M. Linear stapler technique may be safer than circular in gastrojejunal anastomosis for laparoscopic Roux-en-Y gastric bypass: a meta-analysis of comparative studies. Obes Surg 2011;21:1958-1964.

43. Mathus-Vliegen EM. The cooperation between endoscopists and surgeons in treating complications of bariatric surgery. Best Pract Res Clin Gastroenterol 2014;28:703-725.

44. Carrodeguas L, Szomstein S, Zundel N, Lo Menzo E, Rosenthal R. Gastrojejunal anastomotic strictures following laparoscopic Roux-en-Y gastric bypass surgery: analysis of 1291 patients. Surg Obes Relat Dis 2006;2:92-97.

45. Peifer KJ, Shiels AJ, Azar R, Rivera RE, Eagon JC, Jonnalagadda S. Successful endoscopic management of gastrojejunal anastomotic strictures after Roux-en-Y gastric bypass. Gastrointest Endosc 2007;66:248-252.

46. Ukleja A, Afonso BB, Pimentel R, Szomstein S, Rosenthal R. Outcome of endoscopic balloon dilation of strictures after laparoscopic gastric bypass. Surg Endosc 2008;22:1746-1750.

47. Da Costa M, Mata A, Espinós J, et al. Endoscopic dilation of gastrojejunal anastomotic strictures after laparoscopic gastric bypass. Predictors of initial failure. Obes Surg 2011;21:36-41.

48. Barba CA, Butensky MS, Lorenzo M, Newman R. Endoscopic dilation of gastroesophageal anastomosis stricture after gastric bypass. Surg Endosc 2003;17:416-420.

49. Rossi TR, Dynda DI, Estes NC, Marshall JS. Stricture dilation after laparoscopic Roux-en-Y gastric bypass. Am J Surg 2005;189:357-360.

50. Parikh A, Alley JB, Peterson RM, et al. Management options for symptomatic stenosis after laparoscopic vertical sleeve gastrectomy in the morbidly obese. Surg Endosc 2012;26:738-746.

51. Ogra R, Kini GP. Evolving endoscopic management options for symptomatic stenosis post-laparoscopic sleeve gastrectomy for morbid obesity: experience at a large bariatric surgery unit in New Zealand. Obes Surg 2015;25:242-248.

52. Yimcharoen P, Heneghan H, Chand B, et al. Successful management of gastrojejunal strictures after gastric bypass: is timing important? Surg Obes Relat Dis 2012;8:151-157.

53. Ahmad J, Martin J, Ikramuddin S, Schauer P, Slivka A. Endoscopic balloon dilation of gastroenteric anastomotic stricture after laparoscopic gastric bypass. Endoscopy 2003;35:725-728.

54. Go MR, Muscarella P 2nd, Needleman BJ, Cook CH, Melvin WS. Endoscopic management of stomal stenosis after Roux-en-Y gastric bypass. Surg Endosc 2004;18:56-59.

55. Catalano MF, Chua TY, Rudic G. Endoscopic balloon dilation of stomal stenosis following gastric bypass. Obes Surg 2007;17:298-303.

56. Campos JM, Evangelista LF, Ferraz AA, et al. Treatment of ring slippage after gastric bypass: long-term results after endoscopic dilation with an achalasia balloon (with videos). Gastrointest Endosc 2010;72:44-49.

57. de Moura EG, Orso IR, Aurélio EF, de Moura ET, de Moura DT, Santo MA. Factors associated with complications or failure of endoscopic balloon dilation of anastomotic stricture secondary to Roux-en-Y gastric bypass surgery. Surg Obes Relat Dis 2016;12:582-586.

58. Puig CA, Waked TM, Baron TH Sr, Wong Kee Song LM, Gutierrez J, Sarr MG. The role of endoscopic stents in the management of chronic anastomotic and staple line leaks and chronic strictures after bariatric surgery. Surg Obes Relat Dis 2014;10:613-617.

59. Wei W, Ramaswamy A, de la Torre R, Miedema BW. Partially covered esophageal stents cause bowel injury when used to treat complications of bariatric surgery. Surg Endosc 2013;27:56-60.

60. Podnos YD, Jimenez JC, Wilson SE, Stevens CM, Nguyen NT. Complications after laparoscopic gastric bypass: a review of 3464 cases. Arch Surg 2003;138:957-961.

61. Bakhos C, Alkhoury F, Kyriakides T, Reinhold R, Nadzam G. Early postoperative hemorrhage after open and laparoscopic roux-en-y gastric bypass. Obes Surg 2009;19:153-157.

62. Heneghan HM, Meron-Eldar S, Yenumula P, Rogula T, Brethauer SA, Schauer PR. Incidence and management of bleeding complications after gastric bypass surgery in the morbidly obese. Surg Obes Relat Dis 2012;8:729-735.

63. Ferreira LE, Song LM, Baron TH. Management of acute postoperative hemorrhage in the bariatric patient. Gastrointest Endosc Clin N Am 2011;21:287-294.

64. Jamil LH, Krause KR, Chengelis DL, et al. Endoscopic management of early upper gastrointestinal hemorrhage following laparoscopic Rouxen-Y gastric bypass. Am J Gastroenterol 2008;103:86-91.

65. Obstein KL, Thompson CC. Endoscopy after bariatric surgery (with videos). Gastrointest Endosc 2009;70:1161-1166.

66. Heneghan HM, Yimcharoen P, Brethauer SA, Kroh M, Chand B. Influence of pouch and stoma size on weight loss after gastric bypass. Surg Obes Relat Dis 2012;8:408-415.

67. Dakin GF, Eid G, Mikami D, Pryor A, Chand B. Endoluminal revision of gastric bypass for weight regain--a systematic review. Surg Obes Relat Dis 2013;9:335-342.

68. Spaulding L. Treatment of dilated gastrojejunostomy with sclerotherapy. Obes Surg 2003;13:254-257.

69. Spaulding L, Osler T, Patlak J. Long-term results of sclerotherapy for dilated gastrojejunostomy after gastric bypass. Surg Obes Relat Dis 2007:3:623-626 
70. Catalano MF, Rudic G, Anderson AJ, Chua TY. Weight gain after bariatric surgery as a result of a large gastric stoma: endotherapy with sodium morrhuate may prevent the need for surgical revision. Gastrointest Endosc 2007;66:240-245.

71. Loewen M, Barba C. Endoscopic sclerotherapy for dilated gastrojejunostomy of failed gastric bypass. Surg Obes Relat Dis 2008;4:539-542; discussion 542-543.

72. Giurgius M, Fearing N, Weir A, Micheas L, Ramaswamy A. Long-term follow-up evaluation of endoscopic sclerotherapy for dilated gastrojejunostomy after gastric bypass. Surg Endosc 2014;28:1454-1459.

73. Abu Dayyeh BK, Jirapinyo P, Weitzner Z, et al. Endoscopic sclerotherapy for the treatment of weight regain after Roux-en-Y gastric bypass: outcomes, complications, and predictors of response in 575 procedures. Gastrointest Endosc 2012;76:275-282.

74. Mahmood Z, McMahon BP, Arfin Q, et al. Endocinch therapy for gastro-oesophageal reflux disease: a one year prospective follow up. Gut 2003;52:34-39.

75. Thompson CC, Slattery J, Bundga ME, Lautz DB. Peroral endoscopic reduction of dilated gastrojejunal anastomosis after Roux-en-Y gastric bypass: a possible new option for patients with weight regain. Surg Endosc 2006;20:1744-1748.

76. Ryou MK, Abu Dayyeh BK, Yu S, Greenwalt IT, Lautz DB, Thompson CC. Endoscopic revision of dilated gastrojejunostomy in gastric bypass patients experiencing weight regain: a matched cohort comparison of transoral sutured revision versus sclerotherapy versus controls. Gastroenterology 2010;138(5 suppl 1):S-387.

77. Mikami D, Needleman B, Narula V, Durant J, Melvin WS. Natural orifice surgery: initial US experience utilizing the StomaphyX device to reduce gastric pouches after Roux-en-Y gastric bypass. Surg Endosc 2010;24:223-228.

78. Goyal V, Holover S, Garber S. Gastric pouch reduction using StomaphyX in post Roux-en-Y gastric bypass patients does not result in sustained weight loss: a retrospective analysis. Surg Endosc 2013;27:34173420 .

79. Ong'uti SK, Ortega G, Onwugbufor MT, Ivey GD, Fullum TM, Tran DD. Effective weight loss management with endoscopic gastric plication using StomaphyX device: is it achievable? Surg Obes Relat Dis 2013;9:113-117.

80. Ryou M, Mullady DK, Lautz DB, Thompson CC. Pilot study evaluating technical feasibility and early outcomes of second-generation endosurgical platform for treatment of weight regain after gastric bypass surgery. Surg Obes Relat Dis 2009;5:450-454.

81. Mullady DK, Lautz DB, Thompson CC. Treatment of weight regain after gastric bypass surgery when using a new endoscopic platform: initial experience and early outcomes (with video). Gastrointest Endosc 2009;70:440-444.

82. Borao F, Gorcey S, Capuano A. Prospective single-site case series utilizing an endolumenal tissue anchoring system for revision of post-RYGB stomal and pouch dilatation. Surg Endosc 2010;24:2308-2313.

83. Horgan S, Jacobsen G, Weiss GD, et al. Incisionless revision of postRoux-en-Y bypass stomal and pouch dilation: multicenter registry results. Surg Obes Relat Dis 2010;6:290-295.

84. Raman SR, Holover S, Garber S. Endolumenal revision obesity surgery results in weight loss and closure of gastric-gastric fistula. Surg Obes Relat Dis 2011;7:304-308.

85. Heylen AM, Jacobs A, Lybeer M, Prosst RL. The OTSC ${ }^{\oplus}$-clip in revisional endoscopy against weight gain after bariatric gastric bypass surgery. Obes Surg 2011;21:1629-1633.

86. Di Lorenzo N, Lorenzo M, Furbetta F, et al. Intragastric gastric band migration: erosion: an analysis of multicenter experience on 177 patients. Surg Endosc 2013;27:1151-1157.

87. Egberts K, Brown WA, O’Brien PE. Systematic review of erosion after laparoscopic adjustable gastric banding. Obes Surg 2011;21:1272-1279.

88. Dugan J, Bajwa K, Singhal S. Endoscopic removal of gastric band by use of a stent-induced erosion technique. Gastrointest Endosc 2016;83:654655.

89. Meyenberger C, Gubler C, Hengstler PM. Endoscopic management of a penetrated gastric band. Gastrointest Endosc 2004;60:480-481.

90. Marins Campos J, Moon RC, Magalhães Neto GE, et al. Endoscopic treatment of food intolerance after a banded gastric bypass: inducing band erosion for removal using a plastic stent. Endoscopy 2016;48:516520 .

91. Adam LA, Silva RG Jr, Rizk M, Gerke H. Endoscopic argon plasma coagulation of Marlex mesh erosion after vertical-banded gastroplasty. Gastrointest Endosc 2007;65:337-340.

92. Evans JA, Williams NN, Chan EP, Kochman ML. Endoscopic removal of eroded bands in vertical banded gastroplasty: a novel use of endoscopic scissors (with video). Gastrointest Endosc 2006;64:801-804.

93. Regusci L, Groebli Y, Meyer JL, Walder J, Margalith D, Schneider R. Gastroscopic removal of an adjustable gastric band after partial intragastric migration. Obes Surg 2003;13:281-284.

94. Sakai P, Hondo FY, de Almeida Artifon EL, Kuga R, Ishioka S. Symptomatic pneumoperitoneum after endoscopic removal of adjustable gastric band. Obes Surg 2005;15:893-896.

95. Neto MP, Ramos AC, Campos JM, et al. Endoscopic removal of eroded adjustable gastric band: lessons learned after 5 years and 78 cases. Surg Obes Relat Dis 2010;6:423-427.

96. Chisholm J, Kitan N, Toouli J, Kow L. Gastric band erosion in 63 cases: endoscopic removal and rebanding evaluated. Obes Surg 2011;21:16761681.

97. Lee WJ, Chong K, Aung L, Chen SC, Ser KH, Lee YC. Metabolic surgery for diabetes treatment: sleeve gastrectomy or gastric bypass? World J Surg 2017;41:216-223.

98. Lopez-Nava G, Galvão MP, Bautista-Castaño I, Jimenez-Baños A, Fernandez-Corbelle JP. Endoscopic sleeve gastroplasty: how I do it? Obes Surg 2015;25:1534-1538. 